\title{
SISTEM PEMONITOR TINGGI DAN BERAT BADAN UNTUK GIZI PADA BAYI BERBASIS LABVIEW
}

\author{
Hajar Dian Utami ${ }^{1}$, Maharani Destiara Savitri ${ }^{2}$, Supomo $^{3}$ \\ 1,2,35 Jurusan Teknik Elektro, Polteknik Negeri Jakarta, Jl prof.Dr.GA Siwabessy, Kampus Baru UI Depok 16425 \\ e-mail :amidianutami@gmail.com
}

Diterima : 20 Agustus 2019. Disetujui : 17 September 2019. Diterbitkan: Oktober 2019

\begin{abstract}
This article discusses about height and weight measured in babies. Height and weight are parameters to be monitored for parents. Few parents did not realize that the baby's weight also reflects nutrition, which is an important thing to always to be monitored to know the baby's growth. The government through Posyandu organizes a service system to fulfill basic needs, which activities include immunization services, community nutrition education as well as maternal and child health services. In child nutrition checks are weighed and compared with age. Child weighing data is recorded through kartu menuju sehat (KMS). Consequently, it emerges the idea to change the use of manual scales commonly used in posyandu with digital scales which are expected to be able to measure body weight and height accurately as well as facilitate posyandu cadres in monitoring conditions and minimizing the use of kartu menuju sehat. This weight and height measurement tool consists of an ultrasonic sensor which functions as a height gauge as well as a load cell to measure weight with Arduino Uno as data processor that will be displayed with LabVIEW software then stored into Microsoft Excel to minimize the kartu menuju sehat (KMS).
\end{abstract}

Keyword: KMS, Measurement, LabVIEW

\section{ABSTRAK}

Artikel ini membahas tentang pengukuran tinggi dan berat badan pada bayi. Tinggi dan berat merupakan parameter yang penting untuk dipantau bagi orang tua. Tak banyak orang tua yang menyadari bahwa berat badan bayi juga mencerminkan gizi yang merupakan hal penting untuk selalu dipantau pertumbuhannya. Pemerintah melalui posyandu menyelenggarakan sistem pelayanan pemenuhan kebutuhan dasar, kegiatan tersebut meliputi pelayanan imunisasi, pendidikan gizi masyarakat serta pelayanan kesehatan ibu dan anak. Dalam pemeriksaan gizi anak ditimbang dan dibandingkan dengan usia. Data penimbangan anak dicatat melalui kartu menuju sehat (KMS). Oleh karena itu timbul ide untuk merubah penggunaan timbangan manual yang biasa dipakai di posyandu dengan timbangan digital yang diharapkan dapat mengukur berat badan beserta tinggi secara akurasi serta mempermudah kader posyandu dalam memantau kondisi serta meminimalisir penggunaan kartu menuju sehat. Alat pengukur berat dan tinggi ini terdiri dari sensor ultrasonik yang berfungsi sebagai pengukur tinggi dan loadcell untuk mengukur berat dengan Arduino Uno sebagai pengolahan data dan ditampilkan melalui software LabVIEW dan disimpan melalu microsoft excel sehingga meminimalkan penggunaan kartu menuju sehat (KMS). 


\section{PENDAHULUAN}

Sejak bayi gizi mempengaruhi tumbuh kembang anak.. Kurangnya gizi membawa dampak negatif terhadap pertumbuhan fisik maupun mental. Pemerintah melalui posyandu memiliki agenda rutin dalam rangka memantau status gizi dengan melakukan pengukuran berat dan tinggi pada bayi yang dibandingkan dengan usia. Pengukuran berat dan tinggi di posyandu saat ini dilakukan dengan manual. Untuk pengukuran berat menggunakan timbangan konvensional sehingga memberikan hasil yang kurang akurat dan pengukuran tinggi badan menggunakan alat meteran manual sehingga waktu pengukuran menjadi lebih lama. Data penimbangan anak yang dilakukan secara manual dan dicatat melalui kartu menuju sehat (KMS) dapat menimbulkan ketidakakuratan dalam hal pencatatan sehingga mempengaruhi kurva pertumbuhan anak.

Pengukuran berat badan di posyandu saat ini masih dengan model dacin sebagai alat ukur berat badan, dan meteran pita sebagai alat ukur panjang badan balita. Timbangan dacin adalah balok atau beam lurus dengan lengan-lengan yang panjangnya tidak sama, bekerja dengan massa penyeimbang yang digeser di sepanjang lengan untuk menyeimbangkan beban untuk menunjukan berat dengan masa penyeimbang harus dikalibrasi terlebih dahulu [1]. Beberapa peneliti mengembangkan alat ukur alat ukur tinggi dan massa tubuh bayi berbasis mikrokontroler atmega8535 dengan menggunakan sensor PING sebgai pendeteksi tinggi.[2], bebrapa peneliti lainnya juga mengembangkan alat ukur tinggi dengan menggunakan mikrokontroler 8535 dengan sensor fototransistor [3]

Oleh karena itu timbul ide untuk merubah penggunaan timbangan manual yang biasa dipakai di posyandu dengan timbangan digital yang diharapkan dapat mengukur berat badan beserta tinggi secara akurasi serta mempermudah kader posyandu dalam memantau kondisi serta meminimalisir penggunaan kartu menuju sehat. Alat pengukur berat dan tinggi ini terdiri dari sensor ultrasonik yang berfungsi sebagai pengukur tinggi dan loadcell untuk mengukur berat dengan Arduino Uno yang sebagai pengolahan data dan data ditampilkan melalui software LabVIEW.

\section{METODE PENELITIAN}

Perancangan pengukur tinggi dan berat badan terdiri dari sensor ultrasonik sebagai deteksi tinggi dan sensor load cell sebagai deteksi berat dengan modul HX711 sebagai penguat sinyal dan pengkonversi data ADC. Program ditulis di software Arduino IDE dan diupload ke mikrokontroler Arduino Uno, serta data ditampilkan melalui software LabVIEW.

\subsection{Spesifikasi Sistem Pemantau}

a. Sensor Ultrasonik

Sensor ultrasonik HC-SR05 bekerja pada tegangan $5 \mathrm{~V}$ dengan kuat arus listrik $15 \mathrm{~mA}$, rentang jarak yang diukur yaitu dari $2 \mathrm{~cm}$ sampai $300 \mathrm{~cm}$. Sensor ini mendeteksi jarak objek dengan cara memancarkan gelombang ultrasonik $(40 \mathrm{kHz})$ selama tbrust $(200 \mu \mathrm{s})$ kemudian mendeteksi pantulan. Gelombang ultrasonik merambat melalui udara dengan kecepatan $344 \mathrm{~m} / \mathrm{s}$ mengenai objek dan memantul kembali ke sensor [4], seperti pada Gambar 1.

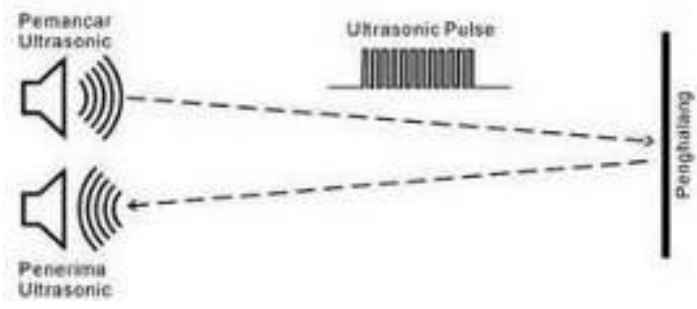

Gambar 1. Prinsip kerja sensor ultrasonik Sumber: http://www.vedcmalang.com /

\section{b. Sensor load cell}

Load cell merupakan alat transmitter yang menghasilkan output proposional dengan beban atau gaya yang diberikan. Load Cell dapat memberikan pengukuran yang akurat dari gaya 
dan beban. Load Cell untuk mengkonversikan regangan pada logam ke tahanan variabel. Load cell umumnya berisi 4 buat strain gange yang tersusun sebagai rangkaian jembatan wheatstone yang disebabkan oleh gaya tekan pada load cell akan diubah menjadi sinyal tegangan. Output Load cell perlu dihubungkan pada modul ADC sebelum ke Arduino[5]

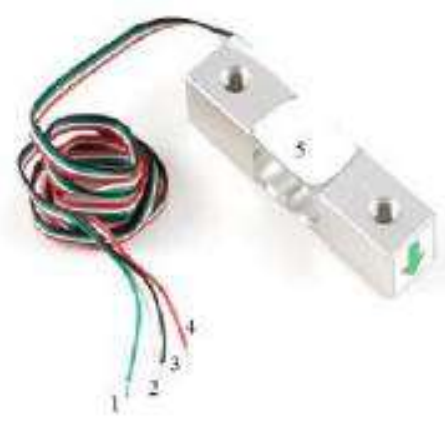

Gambar 2. Sensor Loadcell

Sumber : https://hop.testview.co.il/

Keterangan Gambar 2:

1. Kabel Hijau: output positif sensor

2. Kabel Putih: Output ground sensor

3. Kabel Hitam: Input ground sensor

4. Kabel Merah: Input Tegangan Sensor

5. Silikon Perekat.

Sensor load cell terdiri dari empat buah strain gauge dengan variasi resistansi dalam konfigurasi jembatan wheatstone pada Gambar 3. Perubahan strain akibat gaya tekan benda yang diletakan diatas load cell menyebabkan perubahan tegangan pada jembatan wheatstone.

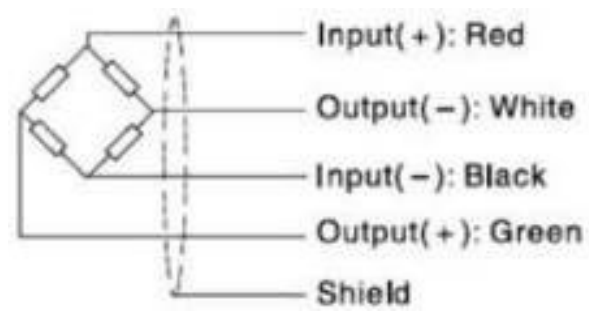

Gambar 3. Rangkaian Jembatan Wheatstone Sumber:http://eprints.mdp.ac.id

\section{c. Modul HX711}

HX711 adalah modul timbangan, yang mempunyai prinsip kerja mengkonversi perubahan yang terukur dalam perubahan resistansi dan mengkonversinya ke dalam besaran tegangan melalui rangkaian yang ada.

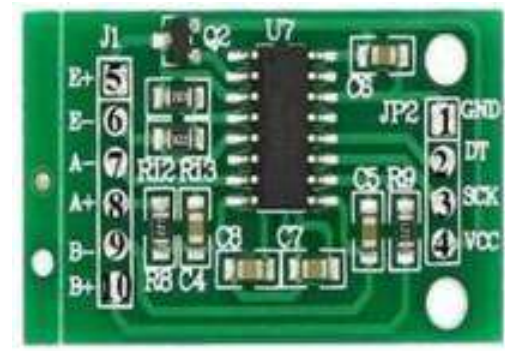

Gambar 4. Modul HX711

Sumber : https://www.tokoarduino.com

Keterangan :

\begin{tabular}{|c|c|}
\hline $\begin{array}{l}\text { GND : } 0 \mathrm{~V} / \text { Ground } \\
\text { Power Connection }\end{array}$ & $\begin{array}{l}\text { E- : } \\
\text { Negative }\end{array}$ \\
\hline DT : Data IO & A-: Channel \\
\hline Connection & Positive Input \\
\hline $\begin{array}{l}\text { SCK : Serial Clock } \\
\text { Input }\end{array}$ & $\begin{array}{l}\text { A+ : Channel } \\
\text { Negative Input }\end{array}$ \\
\hline VCC : Power Input & $\begin{array}{l}\text { B- : Channel } \\
\text { Positive Input }\end{array}$ \\
\hline $\begin{array}{l}\mathrm{E}+\quad: \\
\text { Positive }\end{array}$ & $\begin{array}{l}\mathrm{B}+\text { : Channel } \\
\text { Negative Input }\end{array}$ \\
\hline
\end{tabular}

d. Software LabVIEW

LabVIEW merupakan bahasa pemrograman berbasis grafik untuk instrumentasi, akuisisi data, otomasi dan kontrol serta komunikasi. LabVIEW didesain untuk tidak bergantung pada mesin sehingga dapat ditransfer antar sistem operasi. LabVIEW juga memilki banyak perangkat untuk penanganan fungsi matematika, visualisasi data grafis dan obyek data masukan yang banyak ditemukan pada aplikasi analisis dan akuisisi data [6] Software yang digunakan merupakan NI LabVIEW 2015. 


\subsection{Blok Diagram dan Diagram Alir}

Pada pengukuran tinggi input berasal dari sensor ultrasonik HCSR04 yang membutuhkan 2 pin pada arduino untuk echo dan trigger. Pengukuran berat dengan load cell kapasitas 20 $\mathrm{kg}$ dimana sinyal keluaran dari load cell dikuatkan oleh HX711 dan diolah dengan arduino uno. Untuk dapat menghasilkan kategori gizi parameter dioleh melalui labVIEW sehingga dapat ditampilkan dalam tampilan seperti pada diagram blok keseluruhan sistem pada Gambar 5.

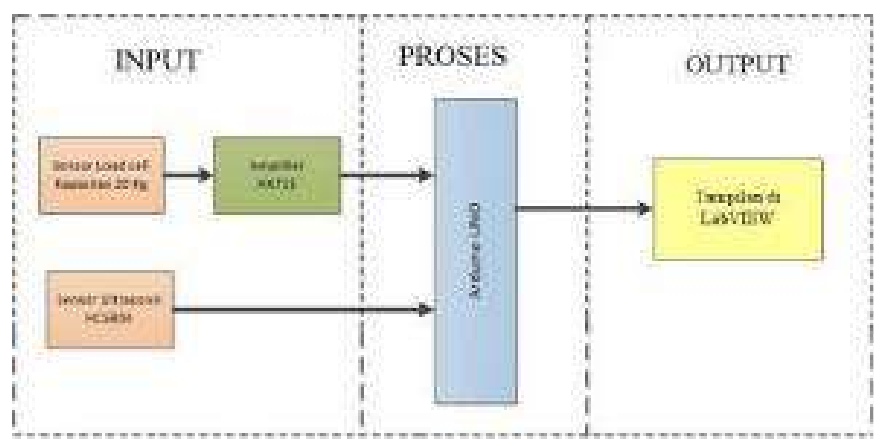

Gambar 5. Diagram Blok Sistem

Dalam sistem pemantau tinggi dan berat badan pada bayi dimulai dengan proses inisialisasi port sensor yang digunakan pada arduino. Sensor ultrasonik mendeteksi hasil pengukuran tinggi dan mencatat hasilnya. Sensor load cell mendeteksi berat berat dengan umur bayi yang telah diinput. Dalam mengolah dan mengelompokkan kategori berat dilakukan oleh software LabVIEW sehingga dapat ditampilkan. Seperti pada diagram alir Gambar 6.
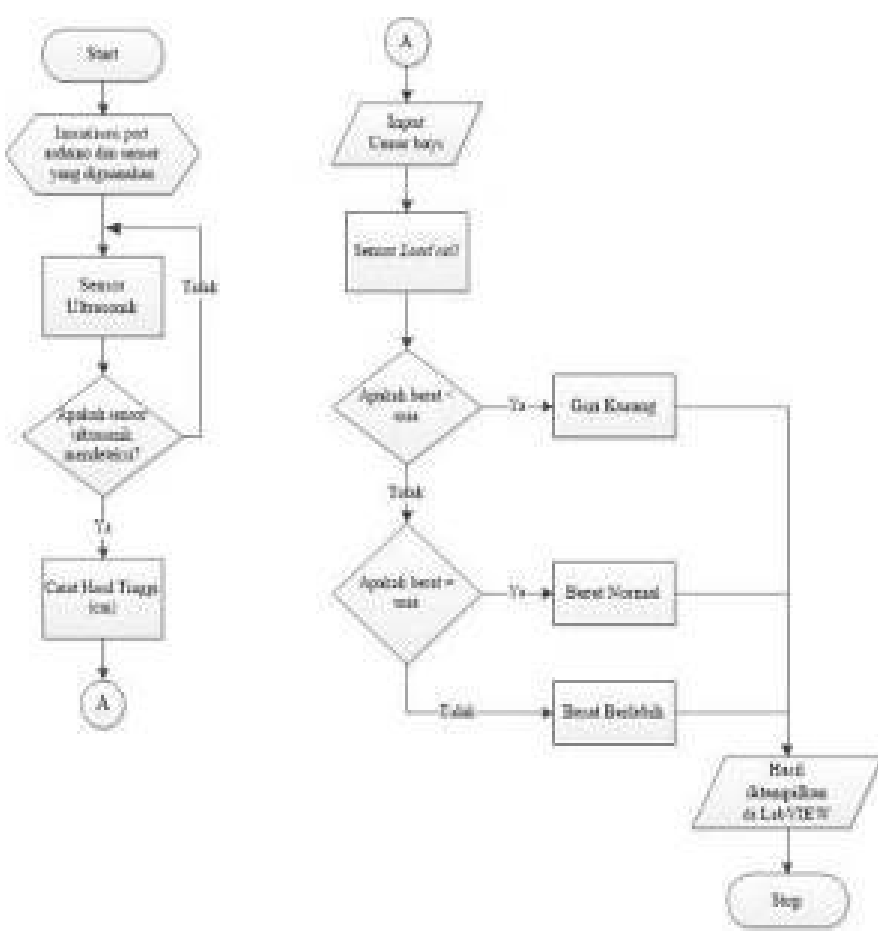

Gambar 6. Diagram Alir Sistem

\subsection{Rangkaian Koneksi Sensor}

a. Rangkaian koneksi sensor ultrasonik Untuk koneksi ultrasonik dengan arduino pin echo pada ultrasonik dihubungkan dengan pin 9 dan untuk trigger di pin 10 pada Arduino, seperti pada Gambar 7.

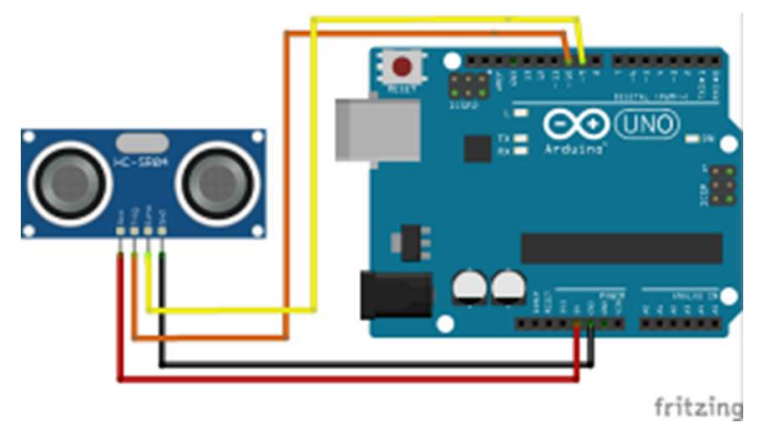

Gambar 7 Koneksi Sensor Ultrasonik KeArduino

Keterangan Gambar 7:

1. Garis Orange trigger terhubung ke pin 9 arduino

2. Garis kuning echo terhubung ke pin 10 arduino

3. Garis Hitam: terhubung ke GND arduino 
4. Garis Merah:terhubung ke VCC arduino

b. Rangkaian koneksi sensor load cell

Sensor loadcell memiliki 4 kabel yang masingmasing dihubungkan ke modul penguat HX711 seperti pada Gambar 8.

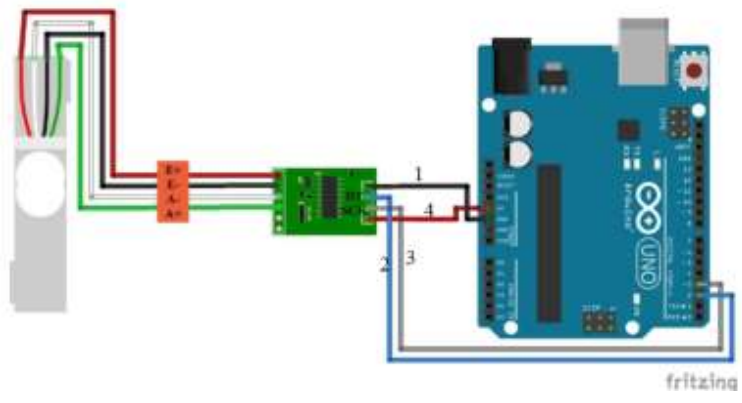

Gambar 8. Koneksi Sensor Load Cell KeArduino

Keterangan Gambar 8:

1. Garis Hitam terhubung ke GND arduino

2. Garis Biru terhubung ke pin 2 digital arduino

3. Garis Abiu-abu: terhubung ke pin 3 digital

4. Garis Merah: terhubung ke VCC arduino

\section{HASIL dan PEMBAHASAN}

3.1. Pengujian sensor

a. Pengujian Sensor Ultrasonik

Pengukuran sensor ultrasonik diawali dengan mengukur panjang alas yaitu

Jarak $=$ Kecepatan $x$ Waktu

Asumsikan menempuh jarak $1 \mathrm{~cm}(1 \mathrm{~cm}=0,01 \mathrm{~m})$ maka dibutuhkan waktu seperti persamaan 2 ,

$$
\begin{aligned}
& \text { waktu }=\frac{\text { jarak }}{\text { kecepatan suara }}=\frac{1 \mathrm{~cm}}{0,0344 \frac{\mathrm{cm}}{\mu \mathrm{s}}} \\
& =29 \mu \mathrm{s}
\end{aligned}
$$

Karena gelombang ultrasonik berpantul dari transmitter ke reciever dan sebaliknya, waktu tempuh yang dibutuhkan 2 kali lipat. Hal ini berpengaruh pada perhitungan jaraknya sehingga menjadi persamaan 3 ,

Waktu tempuh $=29 \mu \mathrm{s} \quad x \quad 2=58 \mu \mathrm{s}$ (3)

Untuk mengetahui nilai error menggunakan persamaan ke-4,

Error $=$

$\frac{\text { Tinggi sebenarnya-Ti pengukuran }}{\text { Tinggi sebenarnya }} \times 100 \%$

Hasil Data pengujian sensor ultrasonik Pengujian dilakukan dengan membandingan hasil pengukuran menggunakan penggaris dengan ultrasonik seprti pada Gambar 9.

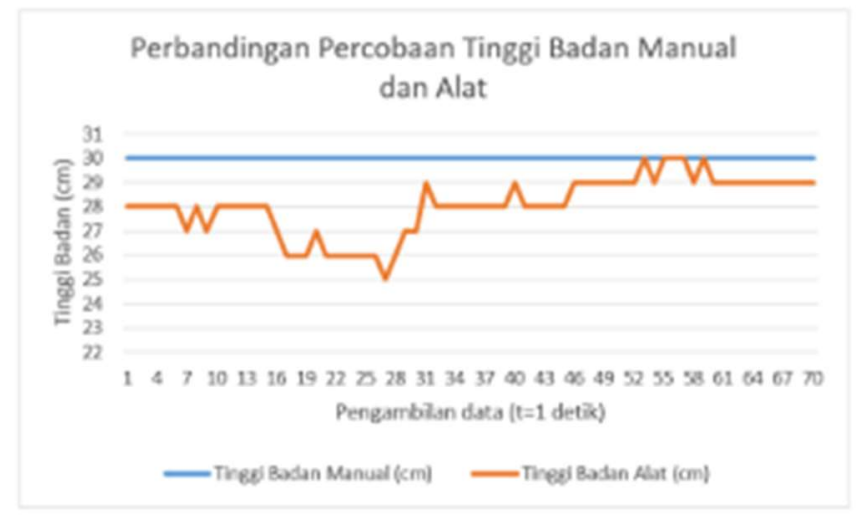

Gambar 9 Perbandingan Tinggi Badan Manual dan Alat

Berdasarkan gambar 9 grafik menunjukkan bahwa detik pertama sampai ke 52 terjadi penurunan hingga titik terendah pada detik ke27 yaitu $25 \mathrm{~cm}$ sehingga rata-rata tinggi bayi adalah $28 \mathrm{~cm}$. Pada detik ke-53 sampai ke-59 tinggi bayi rata-rata $30 \mathrm{~cm}$ sesuai dengan pengukuran manual. Setelah 1 menit pembacaan tinggi bayi cenderung stabil pada angka $29 \mathrm{~cm}$. Sesuai dengan persamaan ke-4 menunjukan terdapat selisih berupa error sebesar 3,33\%.
b. Pengujian sensor load cell
Pengujian dilakukan dengan membandingan hasil pengukuran menggunakan


alat hasil perancangan dengan timbangan manual digital seprti pada gambar 10 .

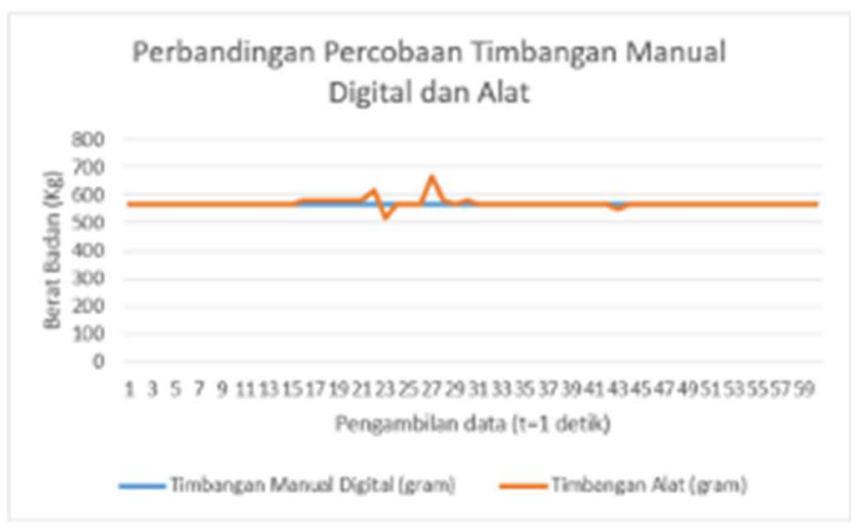

Gambar 10.Grafik perbandingan timbangan manual dan digital

Berdasarkan gambar 10. Grafik rata-rata berat yang terukur ialah 571,6 gram dimana berat sebenarnya 566 gram sehingga terdapat selisih 5,6 gram dari yang sebenarnya sehingga dapat diperoleh kesalahan error sebesar :

$$
\begin{aligned}
\text { Error } & =\frac{566 \mathrm{gram}-571,6 \mathrm{gram}}{566 \mathrm{gram}} \times 100 \% \\
& =0,989 \%
\end{aligned}
$$

\subsection{Diagram Alir Pemrograman LabVIEW}

Dalam pemrograman LabVIEW dimulai dengan menyamakan com diLabVIEW apakah sudah sesuai dengan com dari arduino. Ketika icon run ditekan pada LabVIEW maka proses dimulai dengan membaca inputan dari arduino. Bentuk tipe data string diubah menjadi numerik sehingga LabVIEW dapat mengolah dan mengelompokkan kategori berat dan tinggi sehingga dapat ditampilkan. Seperti pada gambar 11 .
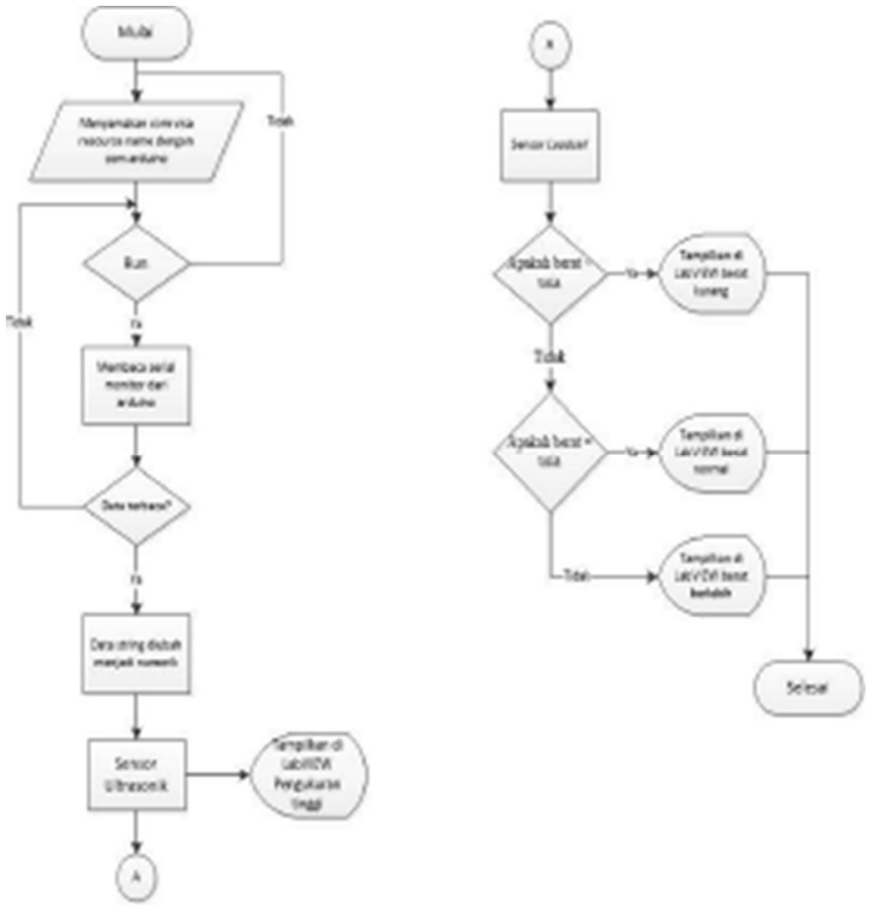

\section{LabVIEW}

\subsection{Hasil Tampilan Front Panel LabVIEW}

Front panel ini berfungsi untuk input identitas data bayi seperti nama dan umur dikolom data, visa resource name pada front panel labview berfungsi menghubungkan com arduino pada labview sehingga arduino dan labview dapat berkomunikasi dan mengirimkan data dari pembacaan sensor ke labview. Output berupa tampilan nama, umur, kategori gizi, tinggi, dan berat. Data pengukuran tersimpan di Ms.Excel hal ini meminimalkan penggunaan kartu menuju sehat (KMS). Hasil pengukuran dapat dilihat pada gambar 12 . 


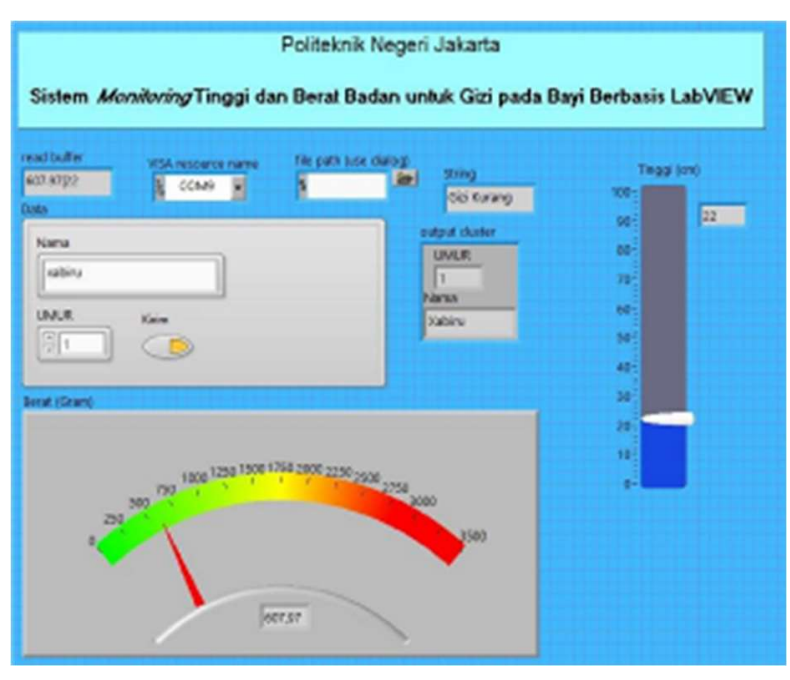

Gambar 12 Hasil Data Pemonitor Tingi Dan Berat

\section{KESIMPULAN}

Berdasarkan data pengujian sensor ultrasonik dapat mendeteksi dengan kesalahan error sebesar 3,36\% sedangkan untuk pengujian sensor load cell error sebesar 0,989\%. Untuk dapat berkomunikasi com antara LabVIEW dan arduino harus sama sehingga dapat menampilkan data berat dan tinggi serta kategori gizi yang sesuai dengan umur.

\section{DAFTAR PUSTAKA}

[1] Apriawan, Dimas Yoga., Lusia Rakhmawati. 2016. "Sistem Pengukur Tinggi Dan Berat Badan Untuk Posyandu Menggunakan Mikrokontroler Atmega 8535". Jurusan Teknik Elektro. Volume 07 Nomor 01, hal 1-8.

[2] Kusumah, Hendra., Alfian Toro, Muhammad Idris. 2018. "Alat Ukur Panjang Dan Berat Badan Balita Untuk Menentukan Kategori Status Gizi Berbasis Arduino Uno". ISSN 1978 8282.
[3] Fajri, Nurul., Wildian. 2014. "Rancang Bangun Alat Ukur Tinggi Dan Berat Badan Bayi Berbasis Mikrokontroler Atmega8535 Dengan Sensor Fototransistor" Jurnal Fisika Unand. VoL.3, No.3.

[4] Yandra, Edwar Frendi, Boni Pahlanop Lapanporo, Muh. Ishak Jumarang. 2016. "Rancang Bangun Timbangan Digital Berbasis Sensor Beban $5 \mathrm{Kg}$ Menggunakan Mikrokontroler Atmega328". Universitas Tanjungpura. POSITRON, Vol. VI, No. 1. Hal 23-28. ISSN : 2301-4970.

[5] Kusriyanto, Medilla. dan Aditya Saputra. 2016.” Rancang Bangun Timbangan Digital Terintegrasi Informasi BMI Dengan Keluaran Suara Berbasis Arduino Mega 2560". Universitas Islam Indonesia. Jurnal Teknoin, Vol 22, No. 4. ISSN : 0853-8697.

[6] Wijaya, Yusmar Palapa. 2015."Simulasi Pengendalian Volume Tangki Menggunakan LabVIEW dan Arduino Uno". Jurnal Sains, Teknologi dan Industri, Vol.13, No.1. Hal 79-82. 